\title{
APAKAH PELAPORAN BERKELANJUTAN MEMODERASI RELEVANSI NILAI INFORMASI AKUNTANSI?
}

\author{
Randy Kuswanto \\ Sekolah Tinggi Ilmu Ekonomi Wiyatamandala \\ randy.kuswanto@wiyatamandala.ac.id
}

\begin{abstract}
This study aims to obtain empirical evidence about the effect of sustainability reporting as a moderating variable on value relevance concept. Prior studies suggest that sustainability report can enhance the company's financial performance which has similar context with value relevance. This study modifies Ohlson Model (1995) with additional moderating variable to capture the effect of sustainability reporting in Indonesia. The population in this study is all public listed company in Indonesia Stock Exchange in 2016. Pair matching and purposive sampling is used as a sampling method to collect 76 samples. The results of this study show sustainability reporting failed to indicate its moderating effect both on the interaction with earning and book value. Nevertheless, value relevance of group who published the sustainability report is higher than the opposite group. As a final result, this study provides empirical evidence that sustainability report cannot increase the firm value in value relevance model but could increase the level of value relevance itself.
\end{abstract}

Keywords: value relevance, sustainability report, book value per share, earning per share, pair matching

\section{PENDAHULUAN}

Riset relevansi nilai menjadi topik yang popular untuk diperdebatkan dalam 20 tahun terakhir (Francis \& Schipper, 1999; Barth, 2000; Ota 2010; Navdal, 2010; Gamerschlag, 2013; Okafor, Anderson and Warsame, 2016; Kuswanto, 2016; Sarumpaet, Nelwan and Dewi, 2017; Badu \& Appiah, 2018). Relevansi nilai mengacu pada hubungan angkaangka akuntansi dalam laporan keuangan dalam keterkaitannya dengan harga dan return saham (Gamerschlag, 2013). Relevansi nilai terjadi apabila angka-angka tersebut secara signifikan dapat mempengaruhi naik-turunnya harga saham perusahaan tersebut. Dengan demikian, informasi yang ada dalam laporan keuangan memiliki nilai prediktif maupun konfirmatif terhadap fenomena relevansi nilai.

Pelaporan keuangan bertujuan untuk menyediakan informasi yang berguna 
untuk investor saat ini dan investor potensial, pemberi pinjaman, dan kreditor lainnya dalam membuat keputusan tentang penyediaan sumber daya (IAI, 2013). Dengan tujuan tersebut, laporan keuangan bukan sebuah produk akhir, melainkan bagian berjalan dalam proses pengambilan keputusan ekonomik oleh penggunanya. Laporan keuangan harus dapat menjadi basis yang dapat membantu investor dalam memilih alternatif keputusan ekonomik yang sifatnya langka (Badu \& Appiah, 2018). Keputusan investor yang mempertimbangkan informasi dalam laporan keuangan akan mempengaruhi harga saham perusahaan tersebut. Salah satu "jembatan" fundamental yang menghubungkan informasi akuntansi dan harga saham ialah relevansi nilai. Topik relevansi nilai sejatinya merupakan topik konvensional yang sudah sering diuji diberbagai penelitian internasional. Tsalavoutas \& Dionysiou (2014) menguji bagaimana pengaruh penerapan IFRS secara mandatory terhadap relevansi nilai di Eropa. Hasil penelitian tersebut menunjukkan bahwa tingkat penerapan IFRS berhubungan dengan relevansi nilai perusahaan. Mostafa (2016) menemukan bahwa laporan laba rugi yang direpresentasikan dengan laba memiliki relevansi lebih tinggi dibandingkan laporan neraca yang direpresentasikan dengan nilai buku ekuitas. Relevansi nilai menjadi alat yang valid sebagai proyeksi dan evaluasi dalam menganalisis hubungan antara angka-angka akuntansi dengan harga saham. Mengingat relevansi nilai menjadi suatu formula teoretis yang masih digunakan hingga sekarang, maka penelitian ini akan menggabungkan elemen konvensional tersebut dengan topik kontemporer yaitu pelaporan berkelanjutan.

Laporan berkelanjutan adalah laporan yang memuat informasi ekonomik, sosial, dan lingkungan terkait aktivitas operasional harian perusahaan (GRI, 2013). Laporan berkelanjutan memuat aspek nonfinansial yang berbeda dengan tujuan laporan keuangan bertujuan umum. Walaupun sifatnya sukarela, terdapat beberapa perusahaan di Indonesia yang telah menerbitkan laporan berkelanjutan. Literatur sebelumnya menyebutkan bahwa informasi berkelanjutan memiliki 
korelasi dan asosiasi terkait kinerja keuangan suatu perusahaan (Velte 2017; Atan dkk. 2017; Sila dan Cek 2017; Buallay 2018). Hal ini menunjukkan bahwa investor juga mempertimbangkan informasi berkelanjutan dalam pengambilan keputusan ekonomik. Dengan demikian, relevansi perusahaan akan ikut terpengaruh dengan adanya tambahan informasi berkelanjutan tersebut.

Pelaporan berkelanjutan masih bersifat sukarela di Indonesia. Namun, beberapa perusahaan terbuka telah menerbitkan laporan berkelanjutan sejak 2006. Caesaria \& Basuki (2017) melakukan penelitian yang menghubungkan ketiga dimensi berkelanjutan terhadap kinerja keuangan perusahaan di Indonesia. Hasil penelitian tersebut menunjukkan bahwa ketiga dimensi berkelanjutan yaitu dimensi ekonomik, sosial, dan lingkungan berpengaruh positif terhadap kinerja keuangan. Temuan penelitian ini menunjukkan bahwa perusahaan yang memperhatikan aspek berkelanjutan dalam aktivitas operasional perusahaan akan menunjang kinerja keuangan yang masih menjadi fokus utama bagi investor. Jika dikaitkan dengan konsep relevansi nilai, maka kinerja yang meningkat akibat dari meningkatnya kinerja berkelanjutan akan menyebabkan meningkatnya nilai perusahaan pula yang tercermin dari harga saham. Sehingga link antara pelaporan berkelanjutan dengan relevansi nilai terbentu.

Penelitian ini bertujuan untuk menguji efek penerbitan laporan berkelanjutan terkait relevansi nilai pada perusahaan terbuka di Indonesia. Kuswanto (2016) menemukan bahwa nilai laba per saham dan nilai buku ekuitas perusahaan memiliki pengaruh positif terhadap harga saham baik secara simultan maupun parsial pada perusahaan manufaktur di Indonesia. Penelitian tersebut membuktikan relevansi nilai juga terjadi di Indonesia. Elemen laporan berkelanjutan akan disematkan untuk menguji apakah dengan adanya laporan berkelanjutan relevansi nilai yang terjadi akan dapat meningkat atau tidak. Peningkatan relevansi nilai akan menunjukkan secara tidak langsung bahwa kinerja berkelanjutan perusahaan juga diperhatikan oleh investor di Indonesia dalam pengambilan keputusan investasi. 
Penelitian ini paling tidak dapat memberikan kontribusi baru bagi konstruk relevansi nilai yang selama ini sudah teruji dalam menilai kekuatan informasi dalam laporan keuangan. Informasi berkelanjutan berpotensi memiliki efek moderasi jika informasi berkelanjutan ialah signifikan bagi investor. Dengan mengikutsertakan variabel pelaporan berkelanjutan dalam formula relevansi nilai maka penelitian ini dapat memberikan suatu temuan yang menghubungkan elemen konvensional dan kontemporer dalam pelaporan korporasi. Investor dapat menggunakan temuan ini dalam meng-assess keputusan investasi. Penelitian ini juga dapat menjadi bukti empiris terkait manfaat laporan berkelanjutan dalam mempertahankan dan meningkatkan nilai perusahaan.

Selanjutnya penelitian ini akan dijelaskan dalam beberapa bagian yaitu bagian (ii) telaah literatur, bagian (iii) metodologi penelitian, bagian (iv) hasil dan analisis, dan bagian terakhir yaitu kesimpulan.

\section{TELAAH LITERATUR Relevansi Nilai}

Relevansi nilai mencerminkan kualitas informasi akuntansi
(Kuswanto, 2016). Keberpautan antara informasi yang dihasilkan dalam siklus akuntansi secara teoretis dan empiris berkaitan dengan nilai perusahaan. Barth, (2000) mendefinisikan secara sederhana bahwa relevansi nilai menganalisis hubungan antara nilai akuntansi dengan nilai pasar ekuitas. Francis dan Schipper (1999) mendefinisikan secara lebih kompleks konsep relevansi nilai dengan membagi menjadi empat pendekatan konsep relevansi nilai antara lain.

1) Pendekatan analisis fundamental, mengungkapkan bahwa informasi akuntansi yang menyebabkan perubahan harga pasar dan mendeteksi terjadinya penyimpangan harga saham.

2) Pendekatan prediksi, bahwa informasi akuntansi dikatakan relevan apabila bermanfaat untuk memprediksi prospek kinerja perusahaan dimasa akan datang.

3) Pendekatan perwujudan informasi nilai relevansi, bahwa informasi akuntansi 
dikatakan relevan apabila ekonomik, sosial, dan lingkungan digunakan investor untuk suatu perusahaan. Laporan menetapkan harga saham.

berkelanjutan berfokus pada elemen

4) Pendekatan pengukuran $3 \mathrm{P}$ (profit, people, and planet). relevansi nilai, bahwa Laporan berkelanjutan berbeda relevansi nilai informasi dengan laporan keuangan. yang terkandung dalam Perbedaannya dapat dijelaskan pada laporan keuangan diukur tabel 1. Tren pelaporan berkelanjutan oleh kemampuannya untuk menangkap dan meringkas informasi bisnis dan aktivitas lainnya.

Berdasarkan penejelasan diatas dapat disimpulkan bahwa relevansi nilai ialah kemampuan angka-angka akuntansi untuk merangkum informasi yang mendasari harga saham sehingga relevansi nilai diindikasikan dengan sebuah hubungan statistikal antara informasi keuangan dan harga atau return saham. Secara teknis, dapat dijelaskan bahwa relevansi nilai merupakan hubungan statistical antara laba dan nilai buku ekuitas perusahaan terhadap harga / return saham perusahaan itu sendiri.

\section{Pelaporan Berkelanjutan}

Laporan berkelanjutan adalah laporan yang menyajikan informasi dimulai sejak 20 tahun yang lalu (Truant, Corazza, dan Scagnelli 2017). Hingga kini, laporan berkelanjutan sudah diterapkan di lebih dari 90 negara dan 13.000 perusahaan di dunia (GRI, 2018).

Pembuatan laporan berkelanjutan menggunakan pedoman GRI. GRI telah menerbitkan standar pelaporan berkelanjutan sejak tahun 2000 dan telah mengeluarkan / merevisi hingga enam kali hingga tahun 2017. Pedoman GRI G4 terdiri dari dua bagian yaitu pengungkapan standar umum dan pengungkapan standar khusus. Pengungkapan standar umum membahas terkait profil organisasi, tata kelola perusahaan, etika dan lain-lain sementara pengungkapan standar khusus membahas tiga informasi berkelanjutan yaitu informasi ekonomik, sosial, dan lingkungan. 
Tabel 1. Perbedaan pelaporan keuangan dan pelaporan berkelanjutan (INTOSAI, 2013)

\begin{tabular}{lll}
\hline & Pelaporan keuangan & Pelaporan berkelanjutan \\
\hline Skala waktu & $\begin{array}{l}\text { Orientasi tahun } \\
\text { pelaporan }\end{array}$ & Orientasi masa depan \\
Fokus & $\begin{array}{l}\text { Isu organisasi yang } \\
\text { berada dalam kendali }\end{array}$ & $\begin{array}{l}\text { Dampak sustainibilitas } \\
\text { yang lebih luas }\end{array}$ \\
Pandangan ekonomik & Material & Tak berwujud \\
Data & Finansial & Nonfinansial \\
Materialitas & Signfikan secara & Informasi manapun \\
& moneter & bergantung pembaca \\
Pengguna & Shareholders & Stakeholders \\
\hline
\end{tabular}

\section{Pengembangan Hipotesis}

Relevansi nilai menunjukkan hubungan antara angka dalam laporan keuangan terhadap nilai saham perusahaan. Korelasi dan asosiasi keduanya yang direpresentasikan secara statistik akan menunjukkan seberapa kuat relevansi yang terjadi. Semakin kuat relevansi nilai maka akan semakin mudah bagi investor untuk mengambil keputusan. Relevansi nilai yang tinggi juga akan mendukung teori pasar efisien dimana harga-harga secara cepat dan tepat merepresentasikan informasi yang ada termasuk informasi akuntansi dalam laporan keuangan. Telah banyak penelitian yang menunjukkan bahwa informasi berkelanjutan dapat meningkatkan kinerja keuangan perusahaan. Jika konsep relevansi dapat dibuktikan, maka pelaporan berkelanjutan seharusnya dapat

meningkatkan kekuatan relevansi nilai tersebut. Sehingga muncul efek moderasi yang ditimbulkan oleh pelaporan berkelanjutan terhadap asosiasi antara nilai laba dan nilai buku ekuitas terhadap harga/return saham. Perusahaan yang menerbitkan laporan berkelanjutan akan cenderung memiliki relevansi nilai yang lebih tinggi dibandingkan perusahaan yang tidak menerbitkan laporan berkelanjutan. Berdasarkan penjelasan diatas, maka hipotesis dalam penelitian ini adalah:

$\begin{aligned} \mathrm{H}_{\mathrm{a}}= & \text { Relevansi nilai informasi } \\ & \text { akuntansi pada perusahaan } \\ & \text { yang menerbitkan laporan } \\ & \text { berkelanjutan lebih tinggi } \\ & \text { dibandingkan perusahaan yang } \\ & \text { tidak menerbitkan laporan } \\ & \text { berkelanjutan. }\end{aligned}$




\section{METODOLOGI PENELITIAN}

Data

Data penelitian ini akan dikelompokkan dalam dua grup. Grup pertama ialah perusahaan yang menerbitkan laporan berkelanjutan dari tahun 2015-2017 sedangkan grup kedua adalah perusahaan yang memiliki karakteristik setara dengan grup pertama namun tidak menerbitkan laporan berkelanjutan. Grup kedua akan menjadi kontrol bagi grup kedua dan akan dibandingkan untuk mengetahui perbedaan relevansi nilai informasi akuntansi antar grup. Setelah itu, kedua grup akan digabungkan dan diuji menggunakan analisis regresi linier berganda dengan memasukkan variable laporan berkelanjutan dalam model Ohlson (1995). Data diambil dari program OSIRIS. Untuk mengetahui apakah perusahaan mengeluarkan laporan berkelanjutan atau tidak penelitian ini akan menggunakan data dari website database.globalreporting.org.

Periode penelitian ini ialah tahun 2016. Studi satu tahun (single-year study) digunakan untuk mengontrol efek informasi lintas waktu dan ketidak konsistenan perusahaan dalam menerbitkan laporan berkelanjutan. Pada tahun 2016 sendiri terdapat 57 perusahaan yang menerbitkan laporan berkelanjutan. Teknik sampling yang digunakan ialah purposive sampling. Kriteria pemilihan sampel yang digunakan untuk menentukan grup pertama ialah sebagai berikut: (1) memublikasikan laporan berkelanjutan tahun 2016; (2) tidak sedang mengalami kerugian; (3) menyajikan dengan mata uang rupiah dan terakhir (4) data input variabel penelitian tersedia. Setelah sampling dilakukan didapatkan 38 perusahaan untuk grup pertama sehingga penelitian ini memiliki 76 sampel penelitian.

\section{Variabel Penelitian}

Variabel dalam penelitian ini terdiri dari variable dependen, independen, dan variabel moderasi. Variabel dependen dalam penelitian ini adalah harga saham perusahaan yang disimbolkan dengan $P_{t}$ Variabel independen dalam penelitian ini adalah nilai laba per saham dan nilai ekuitas per saham yang masingmasing disimbolkan dengan EPS dan BVPS. Terakhir, variabel moderasi 
dalam penelitian ini adalah laporan berkelanjutan. Perusahaan akan diberikan nilai 1 jika menerbitkan laporan berkelanjutan pada periode pelaporan, dan akan diberikan nilai 0 jika tidak menerbitkan laporan berkelanjutan. Laporan berkelanjutan akan disimbolkan dengan kode SR. Selain itu untuk memastikan variabel dependen tidak dipengaruhi oleh variabel lain, maka dua variabel control digunakan dalam penelitian ini yaitu ukuran perusahaan dan jenis industry.

\section{Teknik Analisis Data}

Untuk menguji hipotesis yang diajukan, beberapa proses terkait dilaksanakan. Langkah awal yang dilakukan ialah menentukan sampel dan grup sampling. Perusahaan yang menerbitkan laporan berkelanjutan akan dikelompokkan menjadi grup pertama. Kemudian akan dibentuk sampel pair matching. Teknik pair matching dilakukan dengan cara masing-masing anggota pada sampel dipadankan dengan anggota sampel kontrol dengan karakteristik yang sama sedangkan yang berbeda hanya kategori (Jogiyanto, 2008). Kategori dalam penelitian ini ialah kategori yang menerbitkan laporan berkelanjutan dengan yang tidak menerbitkan laporan berkelanjutan. Sementara, karakteristik yang sama dalam penelitian ini ialah harus berada pada sektor yang sama antara kedua grup.

Terdapat dua analisis untuk menguji hipotesis penelitian. Analisis pertama dilakukan dengan menguji seluruh sampel penelitian dalam rangka menjalankan uji regresi linear berganda. Data dari sampel penelitian akan di uji menggunakan model dibawah ini:

Model 1:

$$
P_{i, t}=\alpha_{0}+\beta_{1} B V P S_{i, t}+\beta_{2} E P S_{i, t}+\beta_{3} S I Z E_{i, t}+\beta_{4} I N D_{i, t}+\varepsilon_{i, t}
$$

Model 2:

\section{Keterangan:}

$$
\begin{aligned}
P_{i, t}=\alpha_{0}+ & \beta_{1} B V P S_{i, t}+\beta_{2} E P S_{i, t}+\beta_{3} S R+\beta_{4} S R * B V P S_{i, t}+\beta_{5} S R * E P S_{i, t} \\
& +\beta_{6} S I Z E_{i, t}+\beta_{7} I N D_{i, t}+\varepsilon_{i, t}
\end{aligned}
$$

$P_{i, t} \quad=$ Harga saham perusahaan i pada tahun fiskal yang berakhir pada tahun t;

$\alpha_{0} \quad=$ Konstanta

$\beta_{1-7} \quad=$ slope untuk setiap variabel

$B V P S_{i, t} \quad=$ nilai buku per lembar saham (book value per share) perusahaan $\mathrm{i}$ untuk tahun fiskal yang berakhir pada tahun t; 
$E P S_{i, t} \quad=$ laba per lembar saham (earnings per share) perusahaan i untuk tahun fiskal yang berakhir pada tahun $\mathrm{t}$;

$S R_{i, t} \quad=$ variabel dummy untuk mengelompokkan sampel berdasarkan pelaporan berkelanjutan;

$S I Z E_{i, t} \quad=$ variabel kontrol, ukuran perusahaan yang diproksikan dengan logaritma natural total penjualan;

$I N D_{i, t} \quad=$ variabel kontrol, diberikan nilai 1 jika non-keuangan dan nilai 0 jika perusahaan keuangan;

$\varepsilon_{i, t} \quad=$ variabel lain yang mempengaruhi variabel dependen;

Analisis pertama bertujuan untuk dicari nilai $\mathrm{R}^{2}$ menggunakan model mengetahu relevansi nilai seluruh regresi pertama dan nilai $\mathrm{R}^{2}$ akan perusahaan dan mengetahui efek dibandingkan. Jika nilai $\mathrm{R}^{2}$ grup pelaporan berkelanjutan terhadap pertama (menerbitkan laporan asosiasi antara nilai-nilai akuntansi berkelanjutan) lebih tinggi terhadap harga saham. Jika slope dibandingkan nilai $\mathrm{R}^{2}$ grup kedua, moderasi teruji positif signifikan, maka dapat ditarik kesimpulan bahwa maka dapat dibuktikan bahwa hipotesis penelitian ini didukung.

pelaporan berkelanjutan memperkuat relevansi nilai pada perusahaan. Sebaliknya, jika slope moderasi teruji negative signifikan, maka dapat dinyatakan bahwa pelaporan berkelanjutan memperlemah relevansi nilai pada perusahaan.

Pada analisis kedua, sampel akan dipisahkan pada grup-grup seperti yang dijelaskan di seksi sebelumnya. Tujuan dikotomi grup ialah untuk melihat kekuatan relevansi nilai antar kelompok. Relevansi nilai dalam riset sebelumnya ditunjukkan pada nilai $\mathrm{R}^{2}$ dari hasil analisis regresi. Semakin tinggi nilai $\mathrm{R}^{2}$, maka semakin tinggi relevansi nilai. Kedua grup akan

\section{HASIL \& ANALISIS}

Untuk menguji efek pelaporan berkelanjutan terhadap relevansi nilai, model penelitian perlu melalui beberapa pengujian. Model penelitian sebelumnya harus melalui pengujian asumsi klasik sebelum melakukan pengujian hipotesis. Terdapat empat uji asumsi klasik yang akan dijabarkan pada paragraf dibawah ini. Sebelumnya karena model satu penelitian tidak memenuhi asumsi normalitas, maka model penelitian akan ditransformasi terlebih dahulu dengan menggunakan logaritma 
natural pada variabel dependen suatu model memiliki gejala penelitian yaitu harga saham $(\mathrm{P})$.

multikolinieritas dapat dilihat dengan

1) Uji Multikolinieritas

Uji multikolinieritas bertujuan untuk nilai VIF dan Tolerance. Pada model menguji antara variabel independen penelitian ini dapat dilihat bahwa nilai VIF lebih dari 10 dan nilai Tolerance tidak memiliki korelasi yang lebih besar dari 0,1 sehingga dapat signifikan. Model yang baik ialah disimpulkan bahwa model penelitian model yang bebas dari asumsi bebas dari gejala multikolinieritas. multikolinieritas. Untuk mengetahui

Tabel 2. Hasil Uji Multikolinieritas

\begin{tabular}{llrc}
\hline \multirow{2}{*}{ Model } & \multicolumn{2}{c}{$\begin{array}{c}\text { Collinearity Statistics } \\
\text { Tolerance }\end{array}$} & \multicolumn{1}{c}{ VIF } \\
\hline 1 & (Constant) & & \\
& BVPS & .332 & 3.011 \\
& EPS & .296 & 3.376 \\
& SIZE & .696 & 1.437 \\
& IND & .983 & 1.017 \\
\hline
\end{tabular}

2) Uji Autokorelasi

Uji autokorelasi dalam penelitian ini menggunaka uji Durbin-Watson (DW). Dalam uji autokorelasi, akan dibandingkan DW tabel dengan DW hitung. Model yang baik harus bebas dari gejala autokorelasi. Untuk bebas dari asumsi tersebut, nilai DW hitung harus berada diantara $\mathrm{Du}$ (Durbin Upper) dan 4-Du. Hasil pengujian autokorelasi menunjukkan bahwa model penelitian bebas dari gejala autokorelasi karena nilai DW hitung sebesar 1,965 berada diantara nilai 1,770 dan (4-1,770)

Tabel 3. Hasil Pengujian Autokorelasi

\begin{tabular}{lrrrrr}
\hline Model & $\mathrm{R}$ & $\begin{array}{c}\mathrm{R} \\
\text { Square }\end{array}$ & $\begin{array}{c}\text { Adjusted R } \\
\text { Square }\end{array}$ & $\begin{array}{c}\text { Std. Error } \\
\text { of the } \\
\text { Estimate }\end{array}$ & $\begin{array}{c}\text { Durbin- } \\
\text { Watson }\end{array}$ \\
\hline 1 & $.824^{\mathrm{a}}$ & .679 & .660 & .85069 & 1.965 \\
\hline
\end{tabular}


3) Uji Heteroskedastisitas

Uji heteroskedastisitas dalam penelitian ini menggunakan uji Spearman rho. Pengujian ini bertujuan untuk menilai apakah ada ketidaksamaan varian dari residual untuk semua pengamatan pada model regresi linear. Untuk bebas dari asumsi heteroskedastisitas, seluruh variabel independen harus memiliki nilai sig. diatas 0,05 . Pada pengujian model penelitian, dapat disimpulkan bahwa model penelitian bebas dari gejala heteroskedastisitas. Selain itu, grafik scatterplot juga tidak menunjukkan pola tertentu sehingga menegaskan bahwa heteroskedastisitas tidak terjadi.

Tabel 4. Hasil Pengujian Heteroskedastisitas

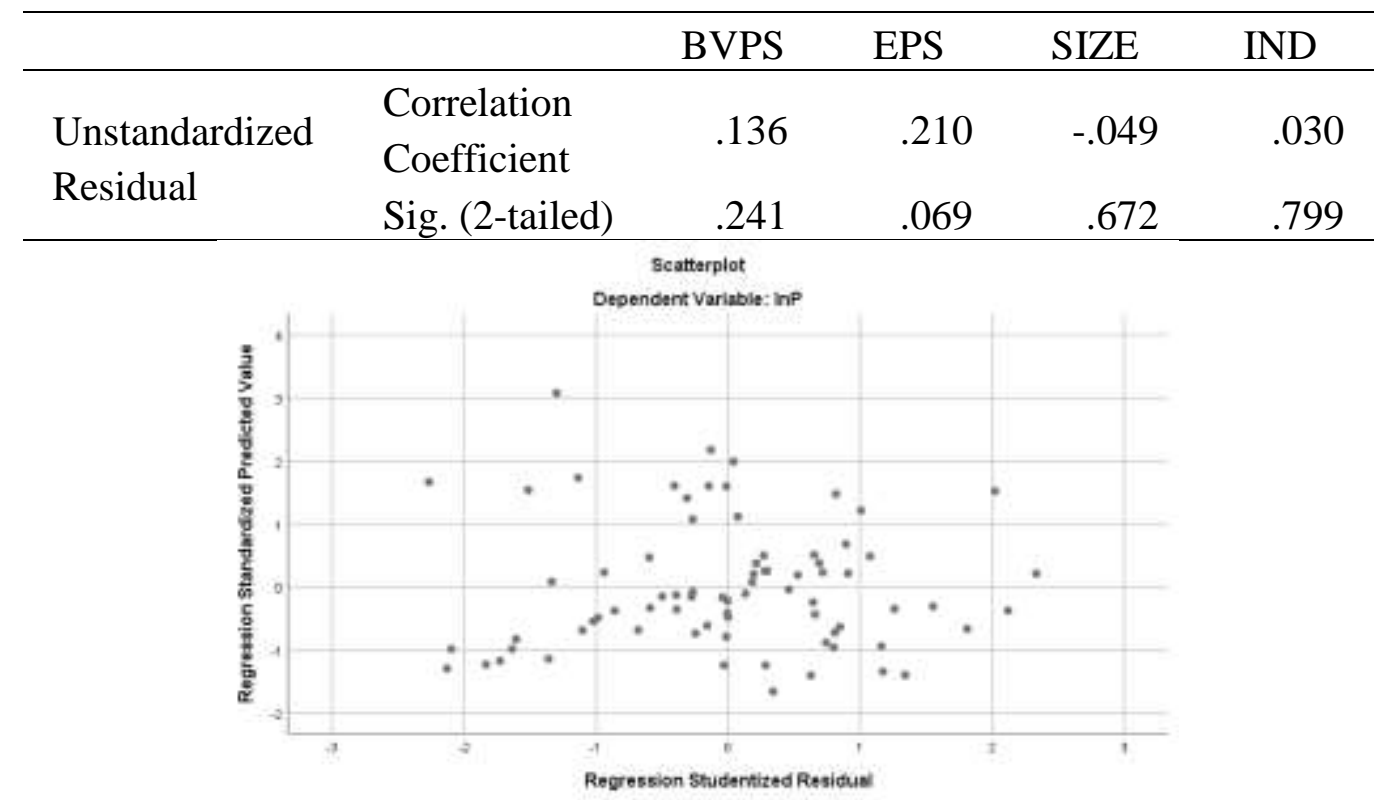

Gambar 1. Scatterplot

4) Uji Normalitas

Uji normalitas bertujuan untuk memastikan bahwa residual model penelitian telah terdistribusi normal. Model yang baik harus memenuhi asumsi normalitas. Pengujian normalitas menggunakan uji Kolmogorov-Smirnov (KS). Jika nilai sig. diatas 0,05 maka dapat dikatakan bahwa model penelitian telah memenuhi asumsi normalitas. Setelah melalui uji normalitas, dapat dilihat bahwa model penelitian yang telah ditransformasi telah memenuhi karakterisitik normalitas sehingga model ini layak untuk diuji regresi linier berganda. 
Tabel 5. Hasil Uji Normalitas

\begin{tabular}{llr}
\hline & & $\begin{array}{c}\text { Unstandardized } \\
\text { Residual }\end{array}$ \\
\hline $\mathrm{N}$ & & 76 \\
Normal Parameters & Mean & .0000000 \\
& Std. & .82769028 \\
& Deviation & \\
Most Extreme & Absolute & .070 \\
Differences & Positive & .048 \\
& Negative & -.070 \\
Test Statistic & & .070 \\
Asymp. Sig. (2-tailed) & & $.200^{\mathrm{c}, \mathrm{d}}$ \\
\hline
\end{tabular}

\section{Pengujian Hipotesis}

Model penelitian satu berguna untuk mengetahui tingkat relevansi nilai pada sampel penelitian. Relevansi nilai dapat direpresentasikan dengan nilai $\mathrm{R}^{2}$ dari hasil uji regresi linier berganda. Hasil regresi linier berganda pada model satu ialah sebagai berikut.

Tabel 6. Hasil Uji Parsial Regresi Linier Berganda

\begin{tabular}{|c|c|c|c|c|c|c|}
\hline \multicolumn{2}{|c|}{ Model } & \multicolumn{2}{|c|}{ Unstandardized Coefficients } & \multirow{2}{*}{$\begin{array}{c}\text { Standardized } \\
\text { Coefficients } \\
\text { Beta }\end{array}$} & \multirow[t]{2}{*}{$\mathrm{t}$} & \multirow[t]{2}{*}{ Sig. } \\
\hline & & $\mathrm{B}$ & Std. Error & & & \\
\hline \multirow[t]{5}{*}{1} & (Constant) & -3.731 & 2.058 & & -1.813 & .074 \\
\hline & BVPS & $8.234 \mathrm{E}-5$ & .000 & .129 & 1.105 & .273 \\
\hline & EPS & .002 & .001 & .401 & 3.246 & .002 \\
\hline & SIZE & .359 & .072 & .403 & 4.996 & .000 \\
\hline & IND & -.487 & .212 & -.156 & -2.299 & .024 \\
\hline
\end{tabular}

Hasil pengujian parsial menunjukkan bahwa laba perusahaan sebagai elemen dari relevansi nilai berpengaruh signifikan terhadap nilai perusahaan. Namun, nilai buku perusahaan tidak berpengaruh signifikan terhadap nilai perusahaan. Koefisien EPS menunjukkan bahwa laba perusahaan berpengaruh positif terhadap harga saham sehingga jika laba perusahaan meningkat, harga saham perusahaan juga akan meningkat. Variabel kontrol menunjukkan pengaruh yang signifikan. Hasil ini menunjukkan bahwa dalam sampel penelitian 
konsep relevansi nilai hanya berlaku yang mana menunjukkan bahwa pada variabel laba perusahaan saja. model telah Goodness of fit yang Walaupun demikian, jika dilihat dari baik. Relevansi nilai dicerminkan dari sampel penelitian saja, kedua elemen nilai $\mathrm{R}^{2}$. Nilai Adjusted $R^{2}$ dalam relevansi nilai yaitu BVPS dan EPS penelitian ini ialah sebesar 66,1\%. sama-sama memiliki nilai beta yang positif sehingga sesuai dengan konsep dari relevansi nilai.

Nilai ini cenderung besar dalam menjelaskan pengaruh variabel independen terhadap variabel

Hasil pengujian simultan dependen. Artinya tingkat relevansi menunjukkan bahwa seluruh variabel independen berpengaruh secara simultan terhadap variabel dependen. Nilai sig. yang dihasilkan ialah 0,000 nilai dalam penelitian ini tergolong kuat dan dapat menjadi basis untuk menjelaskan hipotesis-hipotesis selanjutnya.

Tabel 7. Uji Koefisien Determinasi

\begin{tabular}{crrrr}
\hline Model & R & R Square & $\begin{array}{r}\text { Adjusted } \\
\text { R Square }\end{array}$ & $\begin{array}{r}\text { Std. Error of the } \\
\text { Estimate }\end{array}$ \\
\hline 1 & $.825^{\mathrm{a}}$ & .681 & .661 & .86480 \\
\hline
\end{tabular}

a. Predictors: (Constant), IND, SIZE, BVPS, EPS

Tabel 8. Uji Simultan Regresi Linier Berganda

\begin{tabular}{rlrrrrr}
\hline \multicolumn{2}{l}{ Model } & \multicolumn{1}{c}{$\begin{array}{c}\text { Sum of } \\
\text { Squares }\end{array}$} & df & \multicolumn{1}{c}{$\begin{array}{c}\text { Mean } \\
\text { Square }\end{array}$} & F & \multicolumn{1}{c}{ Sig. } \\
\hline 1 & Regression & 106.749 & 4 & 26.687 & 35.684 & $.000^{\text {b }}$ \\
& Residual & 50.108 & 67 & .748 & & \\
& Total & 156.857 & 71 & & & \\
\hline
\end{tabular}

a. Dependent Variable: $\ln P$

b. Predictors: (Constant), IND, SIZE, BVPS, EPS

\section{Efek Moderasi Laporan}

\section{Berkelanjutan}

Model kedua dalam penelitian ini digunakan untuk menguji efek moderasi dari penerbitan laporan berkelanjutan. Fokus dari pengujian ini ada pada variabel moderasi yang berinteraksi dengan variabel nilai buku per saham dan laba per saham. Jika hasil pengujian menunjukkan signifikansi, maka pelaporan berkelanjutan dapat memoderasi 
relevansi nilai perusahaan. Namun, jika sebaliknya, maka pelaporan berkelanjutan tidak memiliki efek terhadap hubungan nilai laporan keuangan terhadap harga saham.

Hasil pengujian regresi linier berganda menunjukkan bahwa nilai beta kedua interaksi juga menunjukkan nilai negatif yang mengisyaratkan bahwa relevansi nilai pada perusahaan yang menerbitkan laporan berkelanjutan kontradiktif dengan apa yang dihipotesiskan dalam penelitian ini. Namun kedua variabel interaksi pelaporan berkelanjutan dengan nilai buku dan laba perusahaan tidak menunjukkan hasil yang signifikan. Hal ini berarti hipotesis utama dalam penelitian ini tidak dapat dibuktikan. Perusahaan yang menerbitkan laporan berkelanjutan tidak memiliki efek moderasi terhadap relevansi nilai perusahaan. Secara tidak langsung, laporan berkelanjutan tidak memberikan manfaat yang cukup bagi investor dalam meningkatkan kualitas laporan keuangan perusahaan.

Tabel 9. Hasil Uji Parsial dengan Variabel Moderasi

\begin{tabular}{|c|c|c|c|c|c|c|}
\hline & \multirow{2}{*}{ Model } & \multicolumn{2}{|c|}{$\begin{array}{l}\text { Unstandardized } \\
\text { Coefficients }\end{array}$} & \multirow{2}{*}{$\begin{array}{c}\text { Standardized } \\
\text { Coefficients } \\
\text { Beta }\end{array}$} & \multirow{2}{*}{$\mathrm{t}$} & \multirow{2}{*}{ Sig. } \\
\hline & & B & $\begin{array}{l}\text { Std. } \\
\text { Error }\end{array}$ & & & \\
\hline \multirow[t]{8}{*}{1} & (Constant) & -2.579 & 2.422 & & -1.065 & .291 \\
\hline & BVPS & .000 & .000 & .350 & 1.279 & .205 \\
\hline & EPS & .002 & .001 & .414 & 1.292 & .201 \\
\hline & SR & .388 & .306 & .134 & 1.265 & .210 \\
\hline & SRxBVPS & .000 & .000 & -.286 & -.961 & .340 \\
\hline & SRxEPS & $-1.450 \mathrm{E}-6$ & .002 & .000 & -.001 & .999 \\
\hline & SIZE & .312 & .087 & .350 & 3.586 & .001 \\
\hline & IND & -.451 & .214 & -.145 & -2.107 & .039 \\
\hline
\end{tabular}

Temuan ini mengindikasikan bahwa laporan berkelanjutan masih belum memiliki efek moderasi terhadap relevansi nilai perusahaan. Walaupun berbagai penelitian menunjukkan bahwa informasi laporan berkelanjutan dapat meningkatkan kinerja keuangan perusahaan, namun di Indonesia temuan ini tidak memiliki daya moderasi yang dapat meningkatkan nilai perusahaan. Hal ini dapat disebabkan oleh masih rendahnya tingkat pelaporan berkelanjutan di Indonesia. Pada 
tahun 2016, jumlah perusahaan yang terdaftar di BEI yang menerbitkan laporan berkelanjutan hanya $10,3 \%$ sehingga investor dan pengguna laporan berkelanjutan tidak dapat mengukur kinerja berkelanjutan antar perusahaan maupun antar industri. Dampaknya, informasi berkelanjutan tidak dapat menjadi informasi penunjang karena mayoritas perusahaan tidak mengeluarkan informasi tersebut dan informasi tidak memiliki nilai yang material.

\section{Perbandingan Relevansi Nilai}

Relevansi nilai diukur dengan nialai $\mathrm{R}^{2}$. Nilai tersebut didapatkan dari hasil regresi linier berganda. Dalam penelitian ini sampel akan dibagi ke dalam dua kelompok yaitu perusahaan yang menerbitkan laporan berkelanjutan (LB) dan kelompok perusahaanyang tidak menerbitkan laporan berkelanjutan. Tujuan dari analisis ini membandingkan tingkat relevansi nilai antara kedua kelompok tersebut. Hasil analisis menunjukkan bahwa perusahaan yang menerbitkan laporan berkelanjutan memiliki relevansi nilai lebih tinggi dibandingkan perusahaan yang tidak menerbitkan laporan berkelanjutan. Sedikit berbeda dengan hasil analisis sebelumnya. Analisis kali ini bersifat deskriptif yang hanya mengkomparasikan dua kelompok sementara analisis pertama bersifat inferentif yang memiliki daya generalisasi ke populasi yang lebih luas. Relevansi nilai perusahaan yang menerbitkan laporan berkelanjutan ialah $64,2 \%$ nilai ini lebih tinggi dari sampel gabungan dalam analisis pertama. Nilai Adjusted $R^{2}$ kelompok dua ialah sebesar 50,6\%. Terdapat perbedaan sebesar $13,6 \%$ yang menunjukkan perbedaan yang cukup besar antara kedua subsampel. Hasil analisis ini menunjukkan bahwa relevansi nilai perusahaan dengan laporan berkelanjutan dalam sampel penelitian lebih tinggi dibandingkan relevansi nilai perusahaan yang tidak menerbitkan laporan berkelanjutan. Data lebih lengkap dapat dilihat pada tabel dibawah ini. 
Tabel 10. Komparasi Nilai Koefisien Determinasi

\begin{tabular}{lcc}
\hline Deskripsi & Grup dengan LB & Grup tanpa LB \\
\hline R & 0,825 & 0,748 \\
R Square & 0,681 & 0,560 \\
Adjusted $\mathrm{R}^{2}$ & 0,642 & 0,506 \\
\hline
\end{tabular}

\section{KESIMPULAN}

Penelitian ini bertujuan untuk menginvestigasi kaitan pelaporan berkelanjutan dengan relevansi nilai informasi akuntansi perusahaan pada perusahaan yang terdaftar di Bursa Efek Indonesia periode 2016. Hasil penelitian ini menunjukkan bahwa interaksi pelaporan berkelanjutan tidak dapat memoderasi model relevansi nilai atau dalam frase lain tidak dapat meningkatkan nilai perusahaan. Namun, relevansi nilai perusahaan yang mengungkapkan laporan berkelanjutan lebih tinggi dibandingkan perusahaan yang tidak menerbitkan laporan berkelanjutan.

Temuan penelitian ini mengindikasikan bahwa laporan berkelanjutan belum dapat meningkatkan nilai perusahaan sebagai variabel moderasi. Laporan berkelanjutan belum mampu menjadi sebuah informasi signifikan yang dapat meningkatkan kekuatan relevansi nilai pada perusahaan di
Indonesia. Hasil ini disebabkan masih kurangnya animo perusahaan dalam menerbitkan laporan berkelanjutan sehingga investor tidak dapat menjadikan informasi berkelanjutan sebagai suatu faktor yang dipertimbangkan dalam pengambilan keputusan ekonomik.

Penelitian ini memiliki beberapa keterbatasan antara lain ialah kurangnya jumlah sampel penelitian yang disebabkan masih sedikitnya jumlah perusahaan yang menerbitkan laporan berkelanjutan. Keterbatasan yang kedua ialah sampel terdiri dari jenis industri yang bervariasi dan tidak proporsional. Walaupun sudah dikontrol dalam model penelitian perlu adanya spesifikasi industri yang lebih rinci agar model penelitian relevansi lebih akurat. Terakhir, penelitian ini masih menggunakan harga saham penutupan tunggal sehingga efek fluktuasi saham tidak dikendalikan dalam penelitian ini. 
DAFTAR PUSTAKA

Atan, R., Alam, M., Said, J., \& Zamri, M. (2018). The Impact of environmental, social, and governance factors on firm performance: Panel study of Malaysian companies. Management of Environmental Quality: An International Journal , 182-194.

Badu, B., \& Appiah, K. O. (2018). Value relevance of accounting information: an emerging country perspective. Journal of Accounting \& Organizational Change, 473-491.

Barth, M. E. (2000). The Relevance of Value Relevance Research. CA: Stanford University.

Beisland, L. A. (2009). A Review of the Value Relevance Literature. The Open Business Journal, 727.

Bimasakti, D. R. (2014). Relevansi Nilai Aset Takberwujud Pada Perusahaan Manufaktur Yang Terdaftar di Bursa Efek Indonesia. 2014: Universitas Diponegoro.

Buallay, A. (2018). Is sustainability reporting (ESG) associated with performance? Management of Environmental Quality: An International Journal.
Caesaria, A. F., \& Basuki, B. (2017). The study of sustainability report disclosure aspects and their impact on the companies' performance . SHS Web of Conferences 34, (pp. 1-5).

Cahyonowati, N. (2012). Adopsi IFRS dan Relevansi Nilai Informasi Akuntansi. Jurnal Akuntansi dan Keuangan, 105-115.

Francis, J., \& Schipper, K. (1999). Have Financial Statements Lost their Relevance? Journal of Accounting Research, 319-351.

Gamerschlag, R. (2013). Value relevance of human capital information. Journal of Intellectual Capital, 325-345.

Global Reporting Initiative (GRI). (2013). Sustainability Reporting Guidelines. GRI.

Holthausen, R. W. (2001). The Relevance of The Value Relevance Literature for FInancial Accounting Standard Setting. Journal of Accounting and Economics, 3-75.

Ikatan Akuntan Indonesia (IAI). (2013). Pernyataan Standar Akuntansi Keuangan (PSAK) No 1: Penyajian Laporan Keuangan. Jakarta: IAI. 
Initiative, G. R. (2018, 2 18). Sustainability Disclosure Database. Retrieved 2 18, 2018, from Global Reporting: http://database.globalreporting.o $\mathrm{rg} /$

Jogiyanto. (2008). Metodologi Penelitian: Sistem Informasi. Yogyakarta: BPFE.

Kuswanto, R. (2016). Relevansi Nilai Informasi Akuntansi Pada Perusahaan Manufaktur Yang Terdaftar Di Bursa Efek Indonesia Tahun 2013-2014. Tanjungpinang: Universitas Maritim Raja Ali Haji.

Mostafa, W. (2016). The value relevance of earnings, cash flows and book values in Egypt. Management Research Review, 1752-1778.

Navdal, R. (2010). Value Relevance of Accounting Information: Emphasis on the Financial Crisis in 2008. Kristiansand: The University of Agder.

Okafor, O. N., Anderson, M., \& Warsame, H. (2016). IFRS and value relevance: evidence based on Canadian adoption. International Journal of Managerial Finance, 136-160.
Ota, K. (2010). The Value Relevance of Management Forecasts and Their Impact on Analysts' Forecast: Empirical Evidence From Japan. Journal of Accounting, Finance and Business Studies, 28-60.

Puspa, D. F. (2014). The Value Relevance of Accounting Information in Indonesia. Padang: Universitas Andalas.

Sarumpaet, S., Nelwan, M. L., \& Dewi, D. N. (2017). The value relevance of environmental performance: evidence from Indonesia. Social Responsibility Journal, 817-827.

Sila, I., \& Cek, K. (2017). The Impact of Environmental, Social and Governance Dimensions of Corporate Social Responsibility on Economic Performance. International Conference on Theory and application of Soft Computing, Computing with Words and Perception (pp. 797804). Budapest: ICSCCW.

Syagata, G. S. (2014). Analisis Komparasi Relevansi Nilai Informasi Akuntansi Sebelum dan Sesudah Konvergensi IFRS di Indonesia. Diponegoro Journal Of Accounting, 1-11.

Tasalavoutas, I., \& Dionysiou, D. (2014). Value relevance of IFRS mandatory disclosure requirements. Journal of Applied Accounting Research, 22-42. 
Truant, E., Corazza, L., \& Scagnelli, S. Velte, P. (2017). Does ESG

D. (2017). Sustainability and

Risk Disclosure: An

Exploratory Study on

Sustainability Reports.

Sustainability, 1-20.
Performance Have an Impact on Financial Performance?

Journa of

Global 